\title{
PEMBUATAN DEMPLOT BUDIDAYA TANAMAN JAGUNG DALAM MENAMBAH MASA TANAM DI LAHAN KERING DENGAN MEMANFAATKAN PUPUK ORGANIK
}

\author{
Hery Widijanto, Suntoro \\ Fakultas Pertanian, Universitas Sebelas Maret Surakarta \\ Email: herywidijanto@staff.uns.ac.id
}

\begin{abstract}
ABSTRAK
Program IbM ini bekerjasama dengan dua mitra, yaitu: (1) UKM Peternakan Puyuh "Agribird ", dan (2) Kelompok Tani "Mekar Tani". Mitra (1) dan Mitra (2) berlokasi di dukuh Gunung Wijil, Desa Ngringo, Kec. Jaten, Kab. Karanganyar, Jawa Tengah dengan jarak tempuh sekitar $\pm 3,5$ $\mathrm{km}$. Permasalahan utama yang dihadapi oleh mitra usaha „Agribird“e adalah produksi limbah ternak puyuh yang sangat tinggi, yaitu sekitar $300 \mathrm{~kg}$ limbah per hari. Produksi limbahnya sangat tinggi per hari, maka kemampuan produksi limbah jauh melibihi dari kemampuan untuk memanfaatkannya. Bila limbah ini dibuang langsung ke badan sungai terdekat, maka akan mencemari air sungai, sedangkan bila limbah akan diubah menjadi pupuk organik, maka diperlukan teknologi pembuatan pupuk organik. Permasalahan Mitra 2 (Mekar Tani) : lahan yang tiap tahunnya ditanami padi selama 2 kali musim tanam. Musim tanam yang ke-3 diberokan (tidak ditanami), termasuk sawah-sawah petani yang ada di sekitarnya.Solusi yang ditawarkan untuk mengatasi permasalahan utama yang dihadapi mitra (1) adalah teknologi pembuatan pupuk organik yang dapat digunakan sebagai pupuk organik yang sangat bermutu yang dapat digunakan sebagai pupuk organik bagi usaha budidaya tanaman jagung pada mitra (2) yang dapat menambah masa tanam.Kegiatan ini merupakan penerapan Biofilmed Fertilizer yang telah diujikan pada penelitian Pengembangan Biofilmed Biofertilizer Beragens Hayati dari Konsorsia Rhizobiota Bawang Merah (RG Strategis Nasional 2015-2016) serta Teknologi Pengelolaan Limbah untuk Pakan dan Pupuk pada Sistem Pertanian Terpadu Berbasis Perikanan, Peternakan Puyuh dan Sayur Organik (RISTEK - Insinas 2014-2015).
\end{abstract}

Kata kunci : demplot, jagung, masa tanam, lahan kering, pupuk organik

\section{PENDAHULUAN}

Program IbM ini bekerjasama dengan dua mitra, yaitu: (1) UKM Peternakan Puyuh "Agribird ", dan (2) Kelompok Tani "Mekar Tani". Mitra (1) dan Mitra (2) berlokasi di dukuh Gunung Wijil, Desa Ngringo, Kec. Jaten, Kab. Karanganyar, Jawa Tengah dengan jarak tempuh sekitar \pm $3,5 \mathrm{~km}$. Bidang usaha yang dikembangkan oleh mitra (1) tersebut adalah usaha puyuh. Sedangkan Mitra (2) juga berlokasi di dukuh Gunung Wijil, Desa Ngringo, Kec. Jaten, Kab. Karanganyar, Jawa Tengah. Bidang usaha yang dikembangkan oleh mitra (2) tersebut adalah Budidaya Pertanian (padi dan jagung). Lokasi kedua mitra sangat berdekatan, hanya sekitar $0,5 \mathrm{~km}$.

Peternakan puyuh „Agribird"e merupakan usaha mikro milik dr. Agri Vina Brahmantiani. Lokasi kegiatan usaha ini berada di desa Ngringo, Palur, Karanganyar. Manajemen usaha yang dikembangkan berdasarkan manajemen usaha keluarga. „Agribird"e mempekerjakan 4 orang tenaga kerja. Kegiatan usaha yang dikembangkan menempati areal seluas sekitar $2000 \mathrm{~m}^{2}$, dengan jenis usaha: peternakan puyuh, terdiri dari 2 unit rumah puyuh, dengan populasi burung puyuh 12.000 ekor. Kondisi saat ini, kapasitas produksi telur puyuh yang 
dihasilkan adalah rata-rata 8.000 telur puyuh per hari, dan harga telur puyuh rata-rata adalah Rp. 185,- per butir. Usaha puyuh ini telah mensejahterakan keluarga, dan memberikan penghasilan ekonomi yang dapat diunduh setiap hari. Namun demikian, mereka belum mampu melayani permintaan telur puyuh yang tinggi dari konsumen di sekitar Surakarta, sehingga usaha ini memiliki potensi berkembang secara berkelanjutan di masa yang akan datang.

Kelompok Tani Mekar Tani yang diketuai Paliman merupakan kelompok petani yang ada di lingkungan Gunung Wijil.Anggota kelompok tani inisebagian besar merupakan petani "bentil" yang menjadi panutan petani yang ada di sekitarnya, temasuk cara bercocok tanamnya. Paliman mempunyai sebidang tanah yang terletak di Gunung Wijil, Desa Ngringo, Kecamatan Jaten yang merupakan lahan kering.Tiap tahunnya ditanami padi selama 2 kali musim tanam.Musim tanam yang ke-3 diberokan (tidak ditanami), termasuk sawah- sawah petani yang ada di sekitarnya.Tanaman jagung merupakan tanaman musim kemarau yang sangat tanah terhadap kekeringan, apabila dengan perlakuan pupuk organik diharapkan mampu untuk tumbuh lebih baik dan menghasilkan hasil yang sangat tinggi.

Permasalahan utama yang dihadapi oleh mitra usaha „Agribird“e adalah produksi limbah ternak puyuh yang sangat tinggi, yaitu sekitar $300 \mathrm{~kg}$ limbah per hari.Karena produksi limbahnya sangat tinggi per hari, maka kemampuan produksi limbah jauh melibihi dari kemampuan untuk memanfaatkannya. Bila limbah ini dibuang langsung ke badan sungai terdekat, maka akan mencemari air sungai, sedangkan bila limbah akan diubah menjadi pupuk organik, maka diperlukan teknologi pembuatan pupuk organik.

Permasalahan Mitra 2 (Kelompok Tani "Mekar Tani") :Tiap tahunnya ditanami padi selama 2 kali musim tanam. Musim tanam yang ke-3 diberokan (tidak ditanami), termasuk sawah-sawah petani yang ada di sekitarnya.Tanaman jagung merupakan tanaman musim kemarau yang sangat tanah terhadap kekeringan, apabila dengan perlakuan pupuk organik diharapkan mampu untuk tumbuh lebih baik dan menghasilkan hasil yang sangat tinggi. Disamping mengandung hara yang komplit, Pupuk organik bersifat higroskopis mampu menjaga kelengasan air di saat musim kering, yang diharapkan mampu mendukung pertumbuhan jagung pada sat musim kemarau (musim tanam ke-3)

Kegiatan IbM ini berusaha untuk mengatasi permasalahan yang dihadapi mitra usaha dengan memanfaatkan pupuk kandang dari mitra (1) untuk dimanfaatkan sebagai pupuk organik bagi mitra (2). Penerapan teknologi yang diusulkan akan menghasilkan kegiatan usaha terpadu antara peternakan puyuhdanbudidaya tanaman jagungyang ramah lingkungan dan saling menguntungkan.

\section{METODE PENGABDIAN}

Adapun kegiatan yang direncanakan meliputi:Survey awal untuk mengetahui tingkat pengetahuan mitra, kondisi lingkungan dan proses perijinan; Koordinasi dengan mitra untuk menentukan waktu, tempat pelaksanaan serta materi yang dibutuhkan mitra; Penyiapan peralatan dan perlengkapan pelatihan; Penyusunan modul/materi pelatihan; Praktek pembuatan demplot budidaya tanaman jagung dengan memanfaatkan kotoran puyuh yang dikomposkan dengan menggunakan starbio/bakteri dekomposer yang dapat membuat unsur-unsur hara lebih tersedia bagi tanaman dan dapat digunakan sebagai pupuk organic;

Partisipasi mitra dalam pelaksanakan program IbM ini meliputi:Penyediaan kotoran puyuhsebagai bahan pembuatan 
pupuk organic, Penyediaan lokasi demplot budidaya tanaman jagung pupuk dengan memanfaatkan organik dari kotoran puyuh, Penyediaan sumberdaya manusia sebagi subyek untuk dilatih berbagai kegiatan program ini.

\section{HASIL DAN PEMBAHASAN}

\section{Pembuatan Pupuk Organik}

Kegiatan pembuatan pupuk organik yang telah dilaksanakan adalah sebagai berikut:

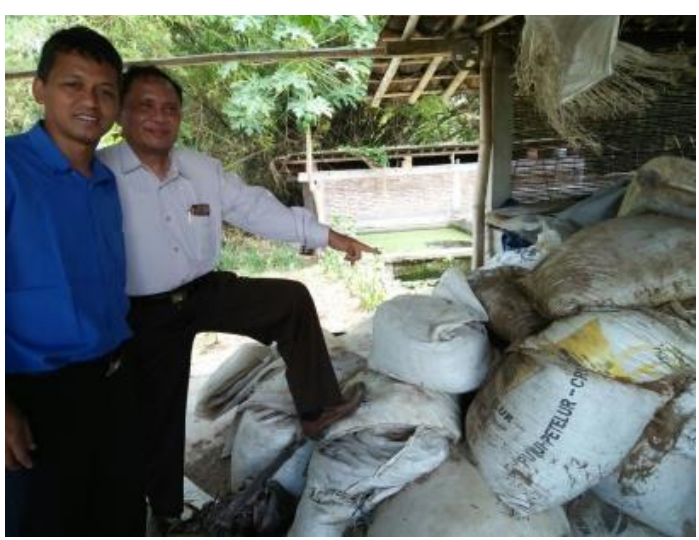

Gambar 1. Tumpukan Kotoran Puyuh yang belum diperlakukan

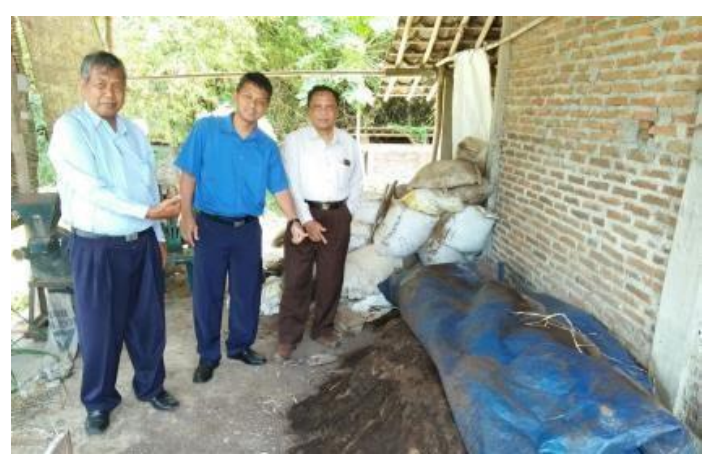

Gambar 2. Kotoran Puyuh yang telah difermentasi

Pemanfaatan kotoran puyuh sebagai bahan pembuatan pupuk organik, akan menghasilkan pupuk organik yang tidak kalah mutunya dengan pupuk kandang dari pedagang.

Pemanfaatan kotoran puyuh untuk bahan pembuatan pupuk organik merupakan wujud nyata dari penerapan peniadaan limbah pada peternakan puyuh. Dengan demikian selain akan memberikan pengurangan biaya produksi mitra (2) juga mitra (1) tidak mencemari lingkungan.

Limbah kotoran puyuh merupakan gabungan antara kotoran puyuh dan limbah pakan, sehingga mengandung berbagai senyawa organik dan unsur-unsur lain yang bermanfaat bagi kehidupan mikrobia tanah.

Pupuk merupakan bahan yang ditambahkan ke dalam tanah untuk menyediakan unsur hara yang penting bagi pertumbuhan tanaman. Penggolongan pupuk umumnya didasarkan pada sumber bahan yang digunakan, cara aplikasi, bentuk dan kandungan unsur haranya. (Hadisuwito,2012)

Pupuk organik merupakan hasil atau sisa hasil akhir dan perubahan atau peruraian bagian-bagian atau sisa-sisa tanaman dan binatang, misalnya pupuk kandang, pupuk hijau, kompos, bungkil, guano, tepung tulang serta limbah-limbah organik yang lain yang telah dikelola dan dapat memasok unsur hara yang dibutuhkan oleh tanaman.

Pupuk organik mempunyai karakteristik kandungan hara rendah, ketersediaan unsur hara lambat, dan menyediakan hara dalam jumlah terbatas dan hara rendah.Ada beberapa manfaat pupuk yang berkaitan dengan sifat kimia tanah. Manfaat pupuk yang paling banyak dirasakan penggunaannnya adalah : menyediakan unsur hara yang diperlukan bagian tanaman, membantu mencegah kehilangan unsur hara yang cepat hilang seperti nitrogen, fosfor dan kalium., memperbaiki keasaman tanah (Marsono, 2001). 


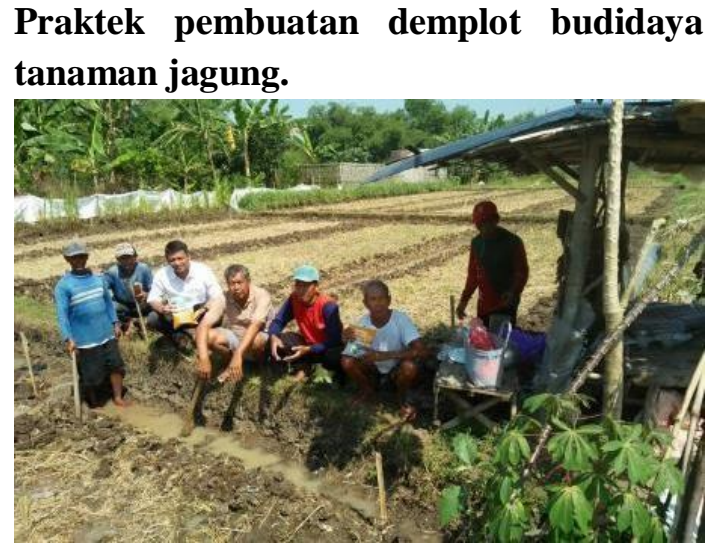

Gambar 3. Koordinasi dengan Mitra Anggota KT Mitra Tani

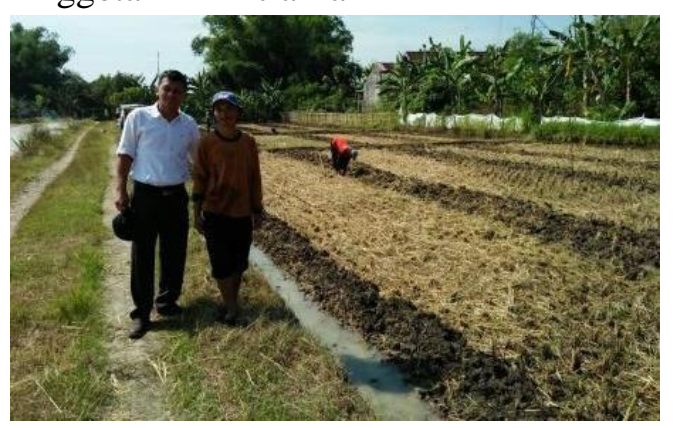

Gambar 4. Lahan Lokasi Demplot

Penanaman Jagung

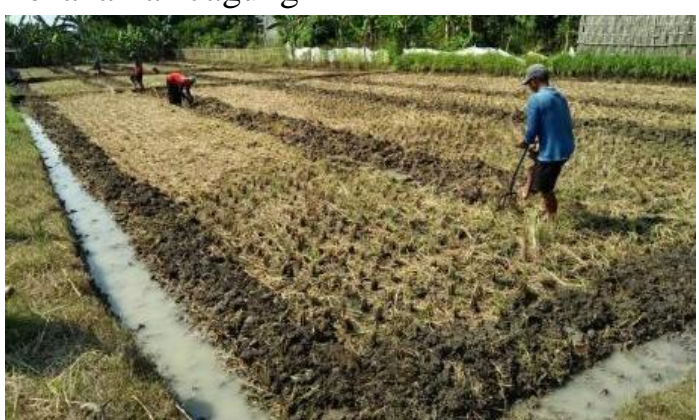

Gambar 5. Proses Pengolahan Tanah dan

Penanaman Jagung

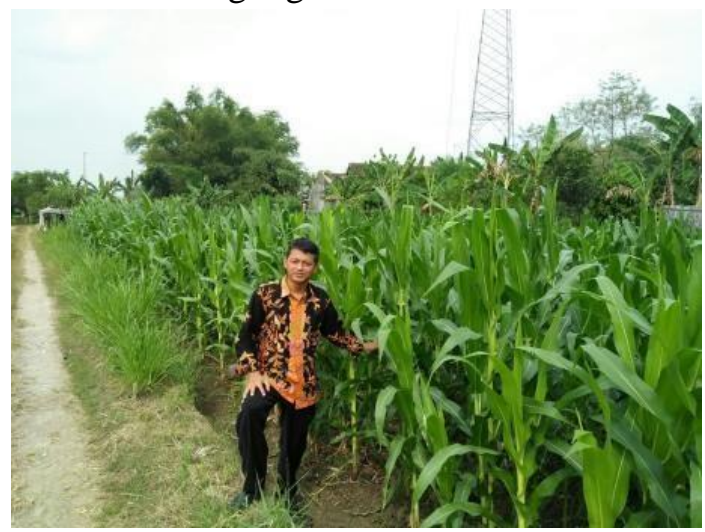

Gambar 6. Demplot Tanaman Jagung
Jagung merupakan tanaman semusim (annual).Satu siklus hidupnya diselesaikan dalam 80-150 hari.Paruh pertama dari siklus merupakan tahap pertumbuhan vegetatif dan paruh kedua untuk tahap pertumbuhan generatif.Susunan morfologi tanaman jagung terdiri dari akar, batang, daun, bunga, dan buah (Wirawan dan Wahab, 2007).

Perakaran tanaman jagung terdiri dari 4 macam akar, yaitu akar utama, akar cabang, akar lateral, dan akar rambut.Sistem perakaran tersebut berfungsi sebagai alat untuk mengisap air serta garam-garam mineral yang terdapat dalam tanah, mengeluarkan zat organik serta senyawa yang tidak diperlukan dan alat pernapasan.Akar jagung termasuk dalam akar serabut yang dapat mencapai kedalaman $8 \mathrm{~m}$ meskipun sebagian besar berada pada kisaran $2 \mathrm{~m}$. Pada tanaman yang cukup dewasa muncul akar adventif dari buku-buku batang bagian bawah yang membantu menyangga tegaknya tanaman (Suprapto, 1999).

Buah jagung terdiri dari tongkol, biji dan daun pembungkus.Biji jagung mempunyai bentuk, warna, dan kandungan endosperm yang bervariasi, tergantung pada jenisnya. Umumnya buah jagung tersusun dalam barisan yang melekat secara lurus atau berkelok-kelok dan berjumlah antara 8-20 baris biji (AAK, 2006).

Pemanfaatan kotoran ternak puyuh sebagai pupuk organik berkualitas, yang dapat digunakan untuk budidaya sayuran organik.Pemanfaatan kotoran ternak puyuh sebagai pupuk organik merupakan wujud nyata dari penerapan zero waste pada peternakan puyuh „Agribird“e secara terpadu. Dengan demikian selain akan memberikan peningkatan penghasilan bagi peternak, dan tidak mencemari lingkungan. 


\section{KESIMPULAN}

Kegiatan pembuatan demplot budidaya tanaman jagung dalam menambah masa tanam di lahan kering dengan memanfaatkan pupuk organikBifertilizer Bio2 hasil riset Perguruan Tinggi di kelompok tani dalam rangka Tri Darma Perguruan Tinggi dapat mengatasi permasalahan mitra melalui teknologi pembuatan pupuk organik yang dapat digunakan sebagai pupuk organik yang sangat bermutu yang dapat digunakan sebagai pupuk organik bagi usaha budidaya tanaman jagung yang dapat menambah masa tanam.

\section{DAFTAR PUSTAKA}

Alimoeso, S. 2006. Revitalisasi Pertanian Menuju Kemandirian Pangan. Disampaikan pada Semnas "Kebijakan, Pendidikan Dan Hasil Penelitian Pertanian" dalam rangka Lustrum XII Fakultas Pertanian Universitas Gadjah Mada.Yogyakarta, 15 - 16 September 2006Rhizobium

Chien, S.Y., C.C. Young \& C.L. Wang. 2007. Current status of Bio-fertilizers, development, farmers" acceptance and utilization and future perspective in Taiwan. FFTC Ext. Bull. 603. p. 1 - 7.

Glaser, B., J. Lehmann and W. Zech. 2002. Ameliorating Physical and Chemical Properties of Highly Weathered Soils in The Tropics with Charcoal -A review. Biology and Fertility of Soils. 35: 219-230.

Rao, N. S., 1994. Mikroorganisme tanah dan pertumbuhan tanaman. UI - pres, Jakarta Richards, B. N. 1987. The Microbiology of Terrestrial Ecosystems. New York: John Willey and Sons Inc.

Zahran, H.H. 2009. Enhancement of Rhizobia- Legumes Symbioses and Nitrogen Fixation for Crops Productivity Improvement. Dalam, M. S. Khan, A. Zaidi \& J. Musarrat., Microbial Strategies for Crop Improvement. Springer-Verlag Berlin Heidelberg. New York. Halm. 227 254. 